\title{
Circle Health's sums do not add up after all
}

\author{
Martin McKee professor of European public health \\ London School of Hygiene and Tropical Medicine, London WC1H 9SH, UK
}

Eighteen months ago I argued that the business case proposed by Circle Health, the company holding the franchise to operate Hinchingbrooke Hospital, simply did not add up. ${ }^{1}$ We now know that, despite asset stripping by selling its car park for $£ 3 \mathrm{~m}$ (€3.5m; \$4.6m), it not only has failed to clear its budget deficit but also is only the second trust to go to the NHS Trust Development Authority for a loan, for $£ 3.5 \mathrm{~m}^{2}$

In its damning report on the award of the franchise, the Commons Public Accounts Committee expressed its concern that "Circle's bid was not properly risk assessed and that Circle was encouraged to submit overly optimistic and unachievable savings projections." ${ }^{3}$ This lesson was clearly not learnt when privatising the NHS 111 service. Now that experience is mounting, it is surely time to publish the risk register for the
Health and Social Care Act to judge whether those ministers responsible for the act were misled or simply reckless.

Competing interests: None declared.

1 McKee M. Circle Health is not like the John Lewis Partnership. BMJ 2011;343:d7897.

IIIman J. Hinchingbrooke applies to DH for £3.5m loan. Health Serv J 2013 Jul 29. www. hsj.co.uk/hsj-local/acute-trusts/hinchingbrooke-health-care-nhs-trust/hinchingbrookeapplies-to-dh-for-35m-loan/5061664. article?blocktitle=News\&contentID=8805.

3 Public Accounts Committee. Report on the franchising of Hinchingbrooke Health Care NHS Trust and Peterborough and Stamford Hospitals NHS Foundation Trust. House of Commons, 2013.

Cite this as: BMJ 2013;347:44898

๑ BMJ Publishing Group Ltd 2013 